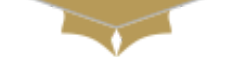

MEDRESEARCH

www.medresearch.in

\section{Surgical Review: International Journal of Surgery Trauma and Orthopedics}

2021 Volume 7 Number 3 May-June

\title{
Comparison of two techniques of steroid injections in the management of Frozen shoulder
}

\author{
Upadhyay S. ${ }^{1}$, Singh S. $^{2 *}$, Varshney A. ${ }^{3}$ \\ DOI: https://doi.org/10.17511/ijoso.2021.i03.04
}

\footnotetext{
${ }^{1}$ Sanjay Upadhyay, Assistant Professor, Atal Bihari Vajpayee Government Medical College (ABVGMC), Vidisha, Madhya Pradesh, India.

2* Sanat Singh, Associate Professor, Atal Bihari Vajpayee Government Medical College (ABVGMC), Vidisha, Madhya Pradesh, India.

3 Atul Varshney, Professor \& HOD, Department of orthopaedics, Atal Bihari Vajpayee Government Medical College (ABVGMC), Vidisha, Madhya Pradesh, India.
}

Background: Frozen shoulder is a condition in which movement of the shoulder becomes restricted. It can be described as either primary (idiopathic) whereby the aetiology is unknown, or secondary, when it can be attributed to another cause. It is commonly a self-limiting condition, of approximately 1 to 3 years' duration, though incomplete resolution can occur. The aetiology of shoulder pain is diverse and includes pathology originating from the neck, glenohumeral joint, acromioclavicular joint, rotator cuff, and other soft tissues around the shoulder girdle. The most common source of shoulder pain is the rotator cuff, accounting for over two-thirds of cases. Material and methods: This was a prospective study with 50 patients coming to our OPD. Patients of all stages were included and randomized into two groups. Group 1: Single Site Injection (SSI) group received steroid injection through posterior approach and Group 2: Novel three-site ( NTS )group received the same dose of steroid in diluted doses at three sites (posterior capsule, subacromial and subcoracoid). The second sitting was repeated after 3 weeks. Both groups had received the same physiotherapy. The patients were evaluated by the CONSTANT score at initial, 3 weeks, 6 weeks and 6 months. Results: Patients of Group 2 (NTS group) had significant pain relief and early improvement in activities of daily living ( $p<0.005$ ) as compared to Group 1 (SSI Group). Also, although there was an improvement in shoulder movements in both the groups but in Group 2 (NTS) patients, early near-normal scores were attained and sustained even after 6 months. About $40 \%$ in Group 1 (SSI) could not attain near-normal levels and had relapses. Conclusion: The Novel threesite approach of steroid injections in frozen shoulder provides early recovery, better pain relief and better improvement in shoulder function with fewer relapses.

Keywords: Constant score, Frozen shoulder, Single site, Novel three-site technique

Corresponding Author

Sanat Singh, Associate Professor, Atal Bihari Vajpayee Government Medical College (ABVGMC), Vidisha, Madhya Pradesh, India.

Email: au1804@gmail.com
How to Cite this Article

Upadhyay S, Singh S, Varshney A. Comparison of two techniques of steroid injections in the management of Frozen shoulder. Surgical Rev Int J Surg Trauma Orthoped. 2021;7(3):57-66. Available From

https://surgical.medresearch.in/index.php/ijoso/artic le/view/226
To Browse

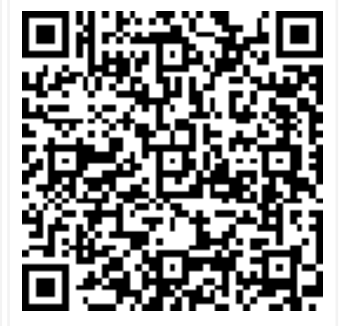

Manuscript Received 2021-03-27

Conflict of Interest No
Review Round 1 2021-04-07

Funding

Nil

Review Round 2
2021-04-14
Ethical Approval
Yes

Review Round 2

Yes
Review Round 3

Plagiarism X-checker $4 \%$
Accepted 2021-04-17

(c) 2021 by Sanjay Upadhyay, Sanat Singh, Atul Varshney and Published by Siddharth Health Research and Social Welfare Society. This is an Open Access article licensed under a Creative Commons Attribution 4.0 International License https://creativecommons.org/licenses/by/4.0/ unported [CC BY 4.0]. 


\section{Background}

Frozen shoulder is a condition in which movement of the shoulder becomes restricted. Frozen shoulder can be a primary or idiopathic when the aetiology is unknown or it may secondary, when associated with another systemic illness. By far the most common association of a secondary frozen shoulder is diabetes mellitus [1]. The incidence of frozen shoulder in diabetes patients is reported to be 10\%-36 [1-3]. The incidence of type 1 and type 2 diabetes is similar [2]. It is commonly a self-limiting condition, of approximately 1 to 3 years duration, though incomplete resolution can occur [4]. Although self-limiting, it can be extremely painful and debilitating affecting the activities of daily living [5]. and there may not be a complete resolution of symptoms in a vast number of cases [6]. There are multiple causes of shoulder pain and may be due to pathology originating from the neck, glenohumeral joint, acromioclavicular joint, rotator cuff, and other soft tissues around the shoulder girdle. The most common source of shoulder pain is the rotator cuff, accounting for over two-thirds of cases [4]. Frozen shoulder patients usually present in the sixth decade of life, and onset before the age of 40 is very uncommon [7]. The peak age is 56, and the condition occurs slightly more often in women than men (8). In $6-17 \%$ of patients, the other shoulder becomes affected, usually within five years, and after the first has resolved. The non-dominant shoulder is slightly more likely to be affected [8].

The condition has a typical clinical course and characteristically passes through three defined stages, progressing

Over several years [8-13].

Stage 1(Acute Or Freezing Stage): Insidious in onset. It consists of gradually increasing pain and stiffness and lasts between 2 months and 9 months [8].

Stage 2 (Frozen or Steady-State Stage): Loss of range of motion is most pronounced in this stage and it lasts between 4 months and 20 months.

Stage 3 ( Thawing or Recovery Stage): It is characterized by resolution of pain and gradual recovery and lasts between 5 months and 26 months $[8,11]$.

Neiaser and Neviaser have described four stages based on the arthroscopic appearance [13].
Stage 1 consists of the pre adhesive stage with inflammatory synovitis and a full range of motion but reports pain [13]. In his classification scheme, stages 2-4 correspond to the classical stages 1-3 as described by Codman [14]. The natural history of this disorder is still poorly understood, and although some researchers $[8,11]$. have demonstrated full recovery, others have shown that it can result in long-term disability $[10,15]$.

Various treatment modalities include benign neglect [16]. oral non-steroidal anti-inflammatory drugs (NSAIDs) [17]. oral corticosteroids [18]. GH intraarticular corticosteroid injections [19]. interventional micro-adhesiolysis [20]. and various physical therapies $[21,22]$. Non-surgical interventions still are the mainstay of treatment. Surgery (manipulation under anesthesia [23]. or supraclavicular blocks [24]. arthroscopic capsular release [25]. or hydrodialation [26]. and open surgical release [27]. is less commonly indicated.

Most commonly performed procedure for frozen shoulder is a steroid injection into the glenohumeral joint followed by therapeutic shoulder exercises [19].

Our study aims to compare the results of the short and long-term efficacy of steroid injection by a novel three-site (NTS) injection technique with the single-site injection (SSI) technique.

\section{Material and methods}

This was a prospective study with 25 patients in each group. All patients of the frozen shoulder of all stages who attended our hospital between July 2018 -June 2020 were included in the study. All patients who are fulfilling the Codman criteria were evaluated with X-ray, ultrasound( in those cases where MRI was not afforded by the patients) and MRI ( magnetic resonance imaging ) of the shoulder to rule out secondary causes like rotator cuff tendinosis, biceps tendinitis, calcification tendinosis etc.

\section{Inclusion criteria:}

- Age- 30-60 years

- No previous joint infection

- Patient willing to comply with shoulder physiotherapy

\section{Exclusion criteria:}

- Age $>60$ years and $<30$ years 
- Associated co-morbidity like DM, deranged thyroid function

- Patient taking steroids and immunosuppressive drugs

- Associated shoulder disorders

Patients were randomized into two groups. Group 1: Single Site Injection (SSI) group received steroid injection through posterior approach and Group 2: Novel three-site ( NTS )group received the same dose of steroid in diluted doses at three sites (posterior capsule, subacromial and subcoracoid)

The test population consisted of 19 female (38\%) and 31 male $(62 \%)$ patients. The right side was involved in $28(56 \%)$ of cases while the left was involved in the remaining $22(44 \%)$ of cases. All cases were right hand dominant.

- In the SSI group, after painting and draping, a single injection of $40 \mathrm{mg}$ of methylprednisolone acetate mixed with $2 \mathrm{ml}$ of $2 \%$ lignocaine was prepared and instilled through the posterior approach ( $2 \mathrm{~cm}$ below and lateral to angle of acromion directed towards coracoid).

- In the NTS group, the same solution was further diluted with $8 \mathrm{ml}$ normal saline and instilled at three sites under all aseptic precaution (a) Posterior site injection: it was given $2 \mathrm{~cm}$ below and lateral to angle of acromion directed towards coracoid. (b) Subacromial site injection: it was above the spine directed towards the acromioclavicular joint through supraspinatus muscle and gradually internal rotating during (c) Subcoracoid site injection: it was obtained by running the needle on subscapularis surface $0.5-1 \mathrm{~cm}$ inferior and lateral to coracoid passing towards the lateral third of coracoid, arm externally rotated during instillation of steroid.

The second sitting was repeated after 3 weeks in both the groups. Both groups had received the same physiotherapy. The patients were evaluated by CONSTANT score (annexure 1) at initial, 3 weeks, 6 weeks and 6 months.

\section{Results}

There was no significant difference in the baseline values of the components of CONSTANT scores. Patients in Group 2(NTS group) had a faster rate of improvement and also attained near-normal scores.

01. Pain: The pain scores had significantly improved at successive visits in both the groups;
However, the improvement in pain scores was much earlier and higher with the three-site injection group $(p<0.0005)$.

01. Activities of daily living (ADL): it improved significantly from the baseline values with subsequent sittings in Group 2(NTS group) but in Group 1 ( SSI group) significant improvements occurred only after the second sittings (after 3 weeks)

\section{Range of Movement( ROM):}

03. Flexion: improvement was comparable with both the groups at all visits.

04. Abduction and External rotation: the improvement was less in Group 1(SSI group) as compared to Group 2 (NTS group) $(p<0.0005)$.

05. Power: No significant improvement was found in both groups.

06. No complication was noted in any group in our study.

No complication was noted in any group in our study.

Table-1: Age distribution in each group

\begin{tabular}{|l|l|l|l|l|}
\hline \multirow{2}{*}{ Age: } & \multicolumn{2}{|c|}{$\begin{array}{c}\text { Group 1 (Single Site } \\
\text { Injection ) }\end{array}$} & \multicolumn{2}{c|}{$\begin{array}{c}\text { Group 2 (Novel Site } \\
\text { Injection) }\end{array}$} \\
\cline { 2 - 6 } & Frequency & $\%$ & Frequency & $\%$ \\
\hline $\begin{array}{l}30-40 \\
\text { years }\end{array}$ & 5 & 20 & 7 & 28 \\
\hline $40-50$ & 12 & 48 & 10 & 30 \\
\hline $50-60$ & 08 & 32 & 08 & 32 \\
\hline Total & 25 & & 25 & \\
\hline
\end{tabular}

Table-2: Gender wise distribution in each group

\begin{tabular}{|l|l|l|l|l|l|}
\hline \multirow{2}{*}{ Sex } & \multicolumn{2}{|c|}{$\begin{array}{c}\text { Group 1 (Single Site } \\
\text { Injection ) }\end{array}$} & \multicolumn{2}{c|}{$\begin{array}{c}\text { Group 2 (Novel Site } \\
\text { Injection) }\end{array}$} & \multirow{2}{*}{ Total } \\
\cline { 2 - 6 } & Frequency & $\%$ & Frequency & $\%$ & \\
\hline Male & 16 & 64 & 15 & 60 & 31 \\
\hline Female & 09 & 36 & 10 & 40 & 19 \\
\hline Total & 25 & & 25 & & 50 \\
\hline
\end{tabular}

Table-3: Side involvement in each group

\begin{tabular}{|l|l|l|l|l|l|}
\hline \multirow{3}{*}{ Side } & \multicolumn{2}{|c|}{$\begin{array}{c}\text { Group 1 (Single Site } \\
\text { Injection ) }\end{array}$} & \multicolumn{2}{c|}{$\begin{array}{c}\text { Group 2 (Novel Site } \\
\text { Injection) }\end{array}$} & \\
\cline { 2 - 5 } & Frequency & $\%$ & Frequency & $\%$ & \\
\hline Right & 15 & 54.5 & 13 & 76.5 & 28 \\
\hline Left & 10 & 45.5 & 12 & 23.5 & 22 \\
\hline Total & 25 & & 25 & & 50 \\
\hline
\end{tabular}

Table-4: Comparison of Constant Score (PAIN) in both groups (Total Score 15) 


\begin{tabular}{|l|l|l|}
\hline Period & \multicolumn{1}{|c|}{$\begin{array}{c}\text { Group 1 (Single Site } \\
\text { Injection) }\end{array}$} & \multicolumn{1}{c|}{$\begin{array}{c}\text { Group 2 (Novel Site } \\
\text { Injection) }\end{array}$} \\
\hline Initial & 8.2 & 8.5 \\
\hline 3 weeks & 9.5 & 11.0 \\
\hline 6 weeks & 11.2 & 13.5 \\
\hline 6 & 13.0 & 14.0 \\
months & & \\
\hline
\end{tabular}

Table-5: Comparison of Constant Score (ACTIVITY OF DAILY LIVING) in both groups (Total score 20)

\begin{tabular}{|l|l|l|}
\hline Period & \multicolumn{1}{|c|}{$\begin{array}{c}\text { Group 1 (Single Site } \\
\text { Injection) }\end{array}$} & \multicolumn{1}{|c|}{$\begin{array}{c}\text { Group 2 (Novel Site } \\
\text { Injection) }\end{array}$} \\
\hline Initial & 10.5 & 9.0 \\
\hline 3 weeks & 12.5 & 13.5 \\
\hline 6 weeks & 14.5 & 16.0 \\
\hline 6 & 15.0 & 17.5 \\
months & & \\
\hline
\end{tabular}

Table-6: Comparison of Constant Score (RANGE OF MOVEMENT) in both groups (Total Score $\mathbf{4 0 \text { ) }}$

\begin{tabular}{|l|l|l|}
\hline Period & \multicolumn{1}{|c|}{$\begin{array}{c}\text { Group 1 (Single Site } \\
\text { Injection) }\end{array}$} & \multicolumn{1}{c|}{$\begin{array}{c}\text { Group 2 (Novel Site } \\
\text { Injection) }\end{array}$} \\
\hline Initial & 25 & 26 \\
\hline 3 weeks & 29 & 32 \\
\hline 6 weeks & 32 & 34 \\
\hline 6 & 34 & 37 \\
months & & \\
\hline
\end{tabular}

Table-7: Comparison of Constant Score (POWER) in both groups (Total score=25)

\begin{tabular}{|l|l|l|}
\hline Period & \multicolumn{1}{|c|}{$\begin{array}{c}\text { Group 1 (Single Site } \\
\text { Injection) }\end{array}$} & \multicolumn{1}{c|}{$\begin{array}{c}\text { Group 2 (Novel Site } \\
\text { Injection) }\end{array}$} \\
\hline Initial & 2.0 & 2.5 \\
\hline 3 weeks & 9.5 & 13.0 \\
\hline 6 weeks & 14.0 & 16.5 \\
\hline 6 & 18.0 & 20.0 \\
months & & \\
\hline
\end{tabular}

Table-8: Comparison of Total Constant Score in both groups (Total Score $=100)$

\begin{tabular}{|l|l|l|}
\hline Period & $\begin{array}{c}\text { Group 1 (Single Site Injection } \\
\text { ) }\end{array}$ & \multicolumn{1}{|c|}{$\begin{array}{c}\text { Group 2 (Novel Site } \\
\text { Injection) }\end{array}$} \\
\hline Initial & 45.7 & 46 \\
\hline 3 weeks & 60.5 & 69.5 \\
\hline 6 weeks & 71.7 & 80 \\
\hline 6 & 80 & 88.5 \\
\hline months & & \\
\hline
\end{tabular}

\section{Discussion}

In 1934, Codman introduced the term "frozen shoulder" [14].
He described it as a painful shoulder condition of insidious onset that was associated with stiffness and difficulty sleeping on the affected side. He also noticed the marked reduction in forwarding elevation and external rotation that are the hallmarks of the disease [14]. In 1872, Duplay described the same condition as "peri-arthritis" [28]. In 1945, Naviesar coined the term "adhesive capsulitis" [13].

The pathophysiology of frozen shoulder is relatively well understood as a pathological process of synovial inflammation followed by capsular fibrosis, but the cause of frozen shoulder is still unknown [29]. Unfortunately, frozen shoulder in diabetes is often more severe and is more resistant to treatment [30]. Moren-Hybbinette et al reported on the natural history of the diabetic painful stiff shoulder and found a restriction in the range of motion in $35(65 \%)$ of 54 shoulders at a mean follow-up of 29 months [31].

Bunker et al have shown an association with Dupuytren's disease in the hand, proposing that the contracting shoulder tissue itself represents a form of fibromatosis [3]. There is inflammation of the capsule and the structures around it followed by fibrosis with type III collagen and the absence of myofibroblasts, basically a Dupuytren-like disease [3]. There occurs contracture of the rotator cuff interval and coracohumeral ligament [33]. subacromial scars, loss of subscapular recess, fibrosis of capsule ligaments complex and a reduced $\mathrm{GH}$ joint volume [34].

Much more rarely, secondary frozen shoulder may be associated with conditions such as hyperthyroidism, hypothyroidism, and hypoadrenalism [7]. Bunker and Anthony revealed that the pathologic process of the frozen shoulder includes active fibroblastic proliferation (3) and Uhthoff and Boileau also focused on the contracture of the anterior capsular structures as the main pathologic process [32]. In 1962, Neviaser described AC as a "contracture and thickening" of the shoulder capsule due to chronic inflammation [13].

The disease process particularly affects the anterosuperior joint capsule and the coracohumeral ligament [35]. Arthroscopy shows a small joint with loss of the axillary fold and tight anterior capsule, mild or moderate synovitis, and no adhesions [36]. Neviaser and Neviaser have described an arthroscopic four-stage classification for the frozen 
Shoulder (13), and Hannafin et al have described a correlation between the arthroscopic stage, the clinical examination, and the histological appearance of the tissues [7]. Evidence shows a synovial inflammation with subsequent reactive capsular fibrosis. A dense matrix of type I and type III collagen is laid down by fibroblasts and myofibroblasts in the joint capsule. Subsequently, this tissue contracts [7].

Increased growth factors, cytokines, and expression of matrix metalloproteinases in capsular biopsy specimens obtained from patients with primary and secondary frozen shoulder indicate that these are involved in the inflammatory and fibrotic cascades seen in the frozen shoulder [7]. Cytokines and growth factors are involved in the initiation and termination of repair processes in musculoskeletal tissues through regulating fibroblasts, and the remodelling process is controlled by matrix metalloproteinases and their inhibitors.

An association between frozen shoulder and Dupuytren's disease has been identified, and this may be related to matrix metalloproteinase inhibitors [7]. In a study by Depalma [33]. he told me there is a contracture of the capsular ligament. There was a restriction in external rotation in the neutral position of the shoulder due to the involvement of coraco- humeral ligament. Also, restriction in external rotation in mid-elevation was found due to contracture of the middle glenohumeral ligament (MGHL) while restriction in external rotation in abduction position was due to contracture of the anterior inferior glenohumeral ligament (AIGHL).

Involvement of inferior capsule causes restriction of abduction in neutral rotation and PIC (posterior inferior capsule) causes internal rotation restriction. In a true frozen shoulder there is an almost complete loss of external rotation. This is the pathognomonic sign of a frozen shoulder [8,37]. In a frozen shoulder, all other movements of the joint are reduced, and if movement occurs this usually comes from the thoracoscapular joint.

Newer studies investigating biomarkers present in the synovial fluid suggest that chronic inflammation is present.

Kim et al compared glenohumeral aspirations from patients with AC (adhesive capsulitis) and healthy controls [38].
In the AC patients, they found elevated levels of intercellular adhesion molecule 1 (ICAM-1 or CD54), a cytokine responsible for stimulating leukocyte activation, proliferation, adhesion, and migration in states of inflammation [38]. Lending support to the idea that chronic inflammation may lead to $A C$, Rodeo et al found an increased presence of TGFbeta and TNF-alpha, other markers of chronic inflammation, in AC shoulders compared with normal shoulders [39]. Finally, Hand et al found both chronic inflammation and fibrosis in biopsies of periarthritis shoulders correlating with the clinical depiction of $\mathrm{AC}$; the progression from pain to stiffness in frozen shoulders suggests inflammation with subsequent fibrosis [40].

Although the diagnosis of frozen shoulder is essentially clinical, there are few specific laboratory tests or radiological markers for frozen shoulder. Immunological studies (such as human leukocyte antigen B27), C reactive protein, and erythrocyte sedimentation rate are all normal and would be measured only to exclude other conditions [7]. Plain radiographs of the frozen shoulder are also normal, although findings like periarticular osteopenia may be seen as a result of disuse [41].

Contrast technetium-99m diphosphonate bone scan shows an increased uptake on the affected side in $92 \%$ of patients compared with the opposite side or with controls [41]. Arthrography shows characteristic findings of limitation of the capacity of the shoulder joint (5-10 ml compared with 25-30 ml in the normal joint) and a small or non-existent dependent axillary fold $[13,41]$. Magnetic resonance imaging may show a slight thickening in the joint capsule and the correct-humeral ligament [7].

Although the natural history of frozen shoulder is for ultimate resolution, this may not be complete. Reeves, in a prospective study of 41 patients with 5-10 years' follow-up, found that 39\% had a full recovery, 54\% had clinical limitation without functional disability, and $7 \%$ had functional limitation [15]. Shaffer et al showed that $50 \%$ of his 61 patients with frozen shoulder had some degree of pain and stiffness an average of seven years after the onset of the disease [37]. Appropriate treatment decisions for frozen shoulder require a comprehensive understanding of pathophysiology, patient's systemic medical condition, functional demands, the severity of symptoms, and response for nonoperative treatment [29]. 
The use of intra-articular steroid injections remains controversial. A Cochrane review from 2003 concluded that it may be beneficial in the short term, but the effect may be small and not maintained [42]. More recently, a meta-analysis by Page et al. reported that a glucocorticoid injection may be more beneficial than a combination of manual therapy and exercise [43].

Steroid injection into the GH (glenohumeral ) joint, accompanied by therapeutic shoulder exercises, is one of the most well-known approaches, regardless of the aetiology for the frozen shoulder $[9,44,45]$. However, low accuracy of injection into the GH joint without radiologic guidance $[46,48]$. the relative ease of access into the subacromial (SA) space, improvement of frozen shoulder symptoms after a SA steroid injection in certain patients, few reports discussing the effects of SA pathology on frozen shoulder, and the effect of steroid injections into the SA space raise questions regarding the etiology of the disease entity and how we should approach this peculiar shoulder disorder $[45,49]$. GH steroid injections are not always effective for primary frozen shoulder.

The inaccuracy of joint injections is likely a major reason for this, because several authors $[46,47]$. have reported a low accuracy of $\mathrm{GH}$ injections without image guidance, reporting a $26.8 \%$ accuracy for the anterior approach [47]. In a study by $\mathrm{O}$ et al., it was found that a single triamcinolone injection in the $\mathrm{GH}$ joint was no superior to the subacromial injections, indicating the multiple pathological sites of the disorder [50].

Rizk et al reported a randomized trial comparing 4 groups:intra-articular methylprednisolone and lidocaine injection, intrabursal methylprednisolone and lidocaine injection, intra-articular lidocaine injection, and intrabursal lidocaine injection. In their study, $40 \mathrm{mg}$ of methylprednisolone was injected weekly for 3 weeks [51].

There was no significant difference in outcomes between intrabursal injections and intra-articular injections. The injection of steroids with lidocaine had no advantage over lidocaine alone in restoring shoulder motion; however, partial, transient pain relief occurred in two-thirds of the steroid-treated patients.

In our study, patients we found that patients in Group 2(NTS group) had significantly more range of abduction, external and internal rotation by about 45o, 30o and 20o, respectively but in Group 1 (SSI group) significant improvements occurred only after the second sittings (after 3 weeks) and two cases of relapses were noted. Corticosteroids participate in numerous physiological pathways, including inflammation and carbohydrate metabolism. They reduce pain and inflammation in the frozen shoulder by inhibiting inflammation and prostaglandin production [52]. It was found that corticosteroid injection worked through systemic rather than local effect, making the accuracy of the injection irrelevant to the treatment [53].

The most common adverse events are injectionrelated pain and skin discolouration at the injection site [54]. Repeated, or misplaced, corticosteroid injections may weaken tendons in the shoulder [55]. Although tendon ruptures have been reported after corticosteroid administration [56,57]. a review examining 744 patients treated with corticosteroid injections for shoulder and elbow tendonitis found no tendon ruptures, suggesting that the risk of tendon damage may be small, especially if injections are given infrequently [54]. In our study, we found no adverse effect except injection-related pain that lasted 2-3 days in few patients in both groups. No skin discolouration or tendon rupture was seen in our study.

Due to the limited sample size and lesser duration of follow-up of our study, we need studies with a big sample size and longer duration of follow up to prove the advantage of one technique over the other. Also, we did not include a control group receiving other treatment modalities, such as physiotherapy with medication only or a placebo injection to eliminate the possibility that a placebo effect was responsible for the improvements.

\section{Conclusion}

We found that in our study, steroids instillation in diluted doses at subcoracoid, subacromial and posterior capsule (group2-NTS) is safe, reliable and has early and near-total functional outcomes with lesser relapses than the traditional single posterior injection(group $1 \mathrm{SSI}$ ).

\section{Reference}

01. Bridgman JF. Periarthritis of the shoulder and diabetes mellitus. Ann Rheum Dis. 1972 Jan;31(1)69-71. doi: 10.1136/ard.31.1.69 [Crossref][PubMed][Google Scholar] 
02. Pal B, Anderson J, Dick WC, Griffiths ID. Limitation of joint mobility and shoulder capsulitis in insulin- and non-insulin-dependent diabetes mellitus. $\mathrm{Br}$ J Rheumatol. 1986 May;25(2)147-51. doi: 10.1093/rheumatology/25.2.147 [Crossref] [PubMed][Google Scholar]

03. Bunker TD, Anthony PP. The pathology of frozen shoulder- A Dupuytren-like disease. J Bone Joint Surg Br. 1995 Sep;77(5)677-83. [Crossref] [PubMed][Google Scholar]

04. Maund E, Craig D, Suekarran S, Neilson A, Wright $K$, Brealey $S$, et al. Management of frozen shoulder: a systematic review and costeffectiveness analysis. Health Technol Assess. 2012;16(11)1-264. doi: 10.3310/hta16110 [Crossref][PubMed][Google Scholar]

05. Dawson J, Shepperd S, Carr A. An overview of factors relevant to undertaking research and reviews on the effectiveness of treatment for frozen shoulder. Shoulder \& Elbow. 2010;2(4)232-237. [Crossref][PubMed][Google Scholar]

06. Hand C, Clipsham K, Rees JL, Carr AJ. Longterm outcome of frozen shoulder. J Shoulder Elbow Surg. 2008 Mar-Apr;17(2)231-6. doi: 10.1016/j.jse.2007.05.009 [Crossref][PubMed] [Google Scholar]

07. Dias R, Cutts S, Massoud S. Frozen shoulder. BMJ. 2005 Dec 17;331(7530)1453-6. doi: 10.1136/bmj.331.7530.1453 [Crossref][PubMed] [Google Scholar]

08. Rizk TE, Pinals RS. Frozen shoulder. Semin Arthritis Rheum. 1982 May;11(4)440-52. doi: 10.1016/0049-0172(82)90030-0 [Crossref] [PubMed][Google Scholar]

09. Bal A, Eksioglu E, Gulec B, Aydog E, Gurcay E, Cakci A. Effectiveness of corticosteroid injection in adhesive capsulitis. Clin Rehabil. 2008 Jun;22(6)503-12. doi: 10.1177/0269215508086179 [Crossref][PubMed][Google Scholar]

10. Binder AI, Bulgen DY, Hazleman BL, Roberts S. Frozen shoulder- a long-term prospective study. Ann Rheum Dis. 1984 Jun;43(3)361-4. doi: 10.1136/ard.43.3.361 [Crossref][PubMed][Google Scholar]

11. Grey RG. The natural history of "idiopathic" frozen shoulder. J Bone Joint Surg Am. 1978 Jun;60(4)564. [Crossref][PubMed][Google Scholar]
12. Jacobs LG, Smith MG, Khan SA, Smith K, Joshi M. Manipulation or intra-articular steroids in the management of adhesive capsulitis of the shoulder? - A prospective randomized trial. J Shoulder Elbow Surg. 2009 May-Jun;18(3)348-53. doi: 10.1016/j.jse.2009.02.002 [Crossref][PubMed] [Google Scholar]

13. Neviaser RJ, Neviaser TJ. The frozen shoulder. Diagnosis and management. Clin Orthop Relat Res. 1987 Oct;(223)59-64 [Crossref][PubMed][Google Scholar]

14. Codman EA. The shoulder. Boston- Todd. 1934. [Crossref][PubMed][Google Scholar]

15. Shaffer B, Tibone JE, Kerlan RK. Frozen shoulder- A long-term follow-up. J Bone Joint Surg Am. 1992 Jun;74(5)738-46. [Crossref][PubMed] [Google Scholar]

16. Lloyd-Roberts Gc, French Pr. Periarthritis of the shoulder- a study of the disease and its treatment. $\mathrm{Br}$ Med J. 1959 Jun 20;1(5137)1569-71. doi: 10.1136/bmj.1.5137.1569 [Crossref][PubMed] [Google Scholar]

17. Duke O, Zecler E, Grahame R. Antiinflammatory drugs in periarthritis of the shouldera double-blind, between-patient study of naproxen versus indomethacin. Rheumatol Rehabil. 1981 Feb 1;20(1)54-9. doi: 10.1093/rheumatology/20.1.54 [Crossref][PubMed][Google Scholar]

18. Buchbinder $\mathrm{R}$, Hoving JL, Green $\mathrm{S}$, Hall $\mathrm{S}$, Forbes A, Nash P. Short course prednisolone for adhesive capsulitis (frozen shoulder or stiff painful shoulder)- a randomised, double blind, placebo controlled trial. Annals of the rheumatic diseases. 2004;63(11)1460-1469. [Crossref][PubMed][Google Scholar]

19. Carette S, Moffet H, Tardif J, Bessette L, Morin F, Frémont $P$, et al. Intraarticular corticosteroids, supervised physiotherapy, or a combination of the two in the treatment of adhesive capsulitis of the shoulder- a placebo-controlled trial. Arthritis Rheum. 2003 Mar;48(3)829-38. doi: 10.1002/art.10954 [Crossref][PubMed][Google Scholar]

20. Ahn K, Lee YJ, Kim EH, Yang SM, Lim TK, Kim $Y S$, et al. Interventional microadhesiolysis- a new nonsurgical release technique for adhesive capsulitis of the shoulder. BMC Musculoskelet Disord. 2008 Jan 29;9;12. doi: 10.1186/1471-2474-9-12 [Crossref][PubMed][Google Scholar] 
21. Vermeulen HM, Rozing PM, Obermann WR, le Cessie S, Vliet Vlieland TP. Comparison of highgrade and low-grade mobilization techniques in the management of adhesive capsulitis of the shoulderrandomized controlled trial. Phys Ther. 2006 Mar;86(3)355-68. [Crossref][PubMed][Google Scholar]

22. Dogru H, Basaran S, Sarpel T. Effectiveness of therapeutic ultrasound in adhesive capsulitis. Joint Bone Spine. 2008 Jul;75(4)445-50. doi: 10.1016/j.jbspin.2007.07.016 [Crossref][PubMed] [Google Scholar]

23. Farrell CM, Sperling JW, Cofield RH. Manipulation for frozen shoulder- long-term results. J Shoulder Elbow Surg. 2005 Sep-Oct;14(5)480-4. doi: 10.1016/j.jse.2005.02.012 [Crossref][PubMed] [Google Scholar]

24. Dahan $T H$, Fortin $L$, Pelletier $M$, Petit $M$, Vadeboncoeur $R$, Suissa $S$. Double blind randomized clinical trial examining the efficacy of bupivacaine suprascapular nerve blocks in frozen shoulder. J Rheumatol. 2000 Jun;27(6)1464-9. [Crossref] [PubMed][Google Scholar]

25. Berghs BM, Sole-Molins $X$, Bunker TD. Arthroscopic release of adhesive capsulitis. J Shoulder Elbow Surg. 2004 Mar-Apr;13(2)180-5. doi: 10.1016/j.jse.2003.12.004 [Crossref][PubMed] [Google Scholar]

26. Buchbinder R, Green S, Youd JM, Johnston RV, Cumpston M. Arthrographic distension for adhesive capsulitis (frozen shoulder). Cochrane Database Syst Rev. 2008 Jan 23;(1)CD007005. doi: 10.1002/14651858.CD007005 [Crossref][PubMed] [Google Scholar]

27. Eid A. Miniopen coracohumeral ligament release and manipulation for idiopathic frozen shoulder. Int J Shoulder Surg. 2012 Jul;6(3)90-6. doi: 10.4103/0973-6042.102561 [Crossref][PubMed] [Google Scholar]

28. Duplay E S. "De la periarthritis scapulohumerale et des radieurs de l'epaule quien son la consequence". Arch Gen Med. 20(1872)513-542. [Crossref][PubMed][Google Scholar]

29. Cho $\mathrm{CH}$, Bae KC, Kim DH. Treatment Strategy for Frozen Shoulder. Clin Orthop Surg. 2019 Sep;11(3)249-257. doi: 10.4055/cios.2019.11.3.249 [Crossref][PubMed] [Google Scholar]
30. Griggs SM, Ahn A, Green A. Idiopathic adhesive capsulitis- A prospective functional outcome study of nonoperative treatment. J Bone Joint Surg Am. 2000 Oct;82(10)1398-407. [Crossref][PubMed] [Google Scholar]

31. Morén-Hybbinette I, Moritz U, Scherstén B. The clinical picture of the painful diabetic shouldernatural history, social consequences and analysis of concomitant hand syndrome. Acta Med Scand. 1987;221(1)73-82. doi: 10.1111/j.09546820.1987.tb01247.x [Crossref][PubMed][Google Scholar]

32. Uhthoff HK, Boileau P. Primary frozen shoulderglobal capsular stiffness versus localized contracture. Clin Orthop Relat Res. 2007 Mar;456;79-84. doi: 10.1097/BLO.0b013e318030846d [Crossref] [PubMed][Google Scholar]

33. DePalma AF. The classic- Recurrent dislocation of the shoulder joint. Ann Surg. 1950;132;10521065. [Crossref][PubMed][Google Scholar]

34. Loyd JA, Loyd HM. Adhesive capsulitis of the shoulder- arthrographic diagnosis and treatment. South Med J. 1983 Jul;76(7)879-83. doi: 10.1097/00007611-198307000-00016 [Crossref] [PubMed][Google Scholar]

35. Ozaki J, Nakagawa Y, Sakurai G, Tamai S. Recalcitrant chronic adhesive capsulitis of the shoulder- Role of contracture of the coraco humeral ligament and rotator interval in pathogenesis and treatment. J Bone Joint Surg Am. 1989 Dec;71(10)1511-5. [Crossref][PubMed][Google Scholar]

36. Ogilvie-Harris DJ, Wiley AM. Arthroscopic surgery of the shoulder- A general appraisal. J Bone Joint Surg Br. 1986 Mar;68(2)201-7. doi: 10.1302/0301-620X.68B2.3958003 [Crossref] [PubMed][Google Scholar]

37. Reeves B. The natural history of the frozen shoulder syndrome. Scand J Rheumatol. 1975;4(4)193-6. doi: 10.3109/03009747509165255 [Crossref][PubMed] [Google Scholar]

38. Kim YS, Kim JM, Lee YG, Hong OK, Kwon HS, Ji JH. Intercellular adhesion molecule-1 (ICAM-1, CD54) is increased in adhesive capsulitis. J Bone Joint Surg Am. 2013 Feb 20;95(4)e181-8. doi: 10.2106/JBJS.K.00525 [Crossref][PubMed][Google Scholar] 
39. Rodeo SA, Hannafin JA, Tom J, Warren RF, Wickiewicz TL. Immunolocalization of cytokines and their receptors in adhesive capsulitis of the shoulder. J Orthop Res. 1997 May;15(3)427-36. doi: 10.1002/jor.1100150316 [Crossref][PubMed] [Google Scholar]

40. Hand GC, Athanasou NA, Matthews T, Carr AJ. The pathology of frozen shoulder. J Bone Joint Surg Br. 2007 Jul;89(7)928-32. doi: 10.1302/0301620X.89B7.19097 [Crossref][PubMed][Google Scholar]

41. Binder AI, Bulgen DY, Hazleman BL, Tudor J, Wraight P. Frozen shoulder- an arthrographic and radionuclear scan assessment. Ann Rheum Dis. 1984 Jun;43(3)365-9. doi: 10.1136/ard.43.3.365. PMID: 6742897; [Crossref][PubMed][Google Scholar]

42. Buchbinder $\mathrm{R}$, Green $\mathrm{S}$ and Youd JM. Corticosteroid infections for shoulder pain. Cochrane Database Syst Rev. 2003;1;CD004016. [Crossref] [PubMed][Google Scholar]

43. Page MJ, Green S, Kramer S, Johnston RV, McBain B, Chau M, et al. Manual therapy and exercise for adhesive capsulitis (frozen shoulder). Cochrane Database Syst Rev. 2014 Aug 26; (8)CD011275. doi: 10.1002/14651858.CD011275 [Crossref][PubMed][Google Scholar]

44. Carette S, Moffet H, Tardif J, Bessette L, Morin F, Frémont $P$, et al. Intraarticular corticosteroids, supervised physiotherapy, or a combination of the two in the treatment of adhesive capsulitis of the shoulder- a placebo-controlled trial. Arthritis Rheum. 2003 Mar;48(3)829-38. doi: 10.1002/art.10954 [Crossref][PubMed][Google Scholar]

45. Ryans I, Montgomery A, Galway R, Kernohan WG, McKane R. A randomized controlled trial of intra-articular triamcinolone and/or physiotherapy in shoulder capsulitis. Rheumatology (Oxford). 2005 Apr;44(4)529-35.

doi:

10.1093/rheumatology/keh535 [Crossref][PubMed] [Google Scholar]

46. Eustace JA, Brophy DP, Gibney RP, Bresnihan B, FitzGerald O. Comparison of the accuracy of steroid placement with clinical outcome in patients with shoulder symptoms. Ann Rheum Dis. 1997 Jan;56(1)59-63. doi: 10.1136/ard.56.1.59 [Crossref][PubMed][Google Scholar]
47. Sethi PM, Kingston S, Elattrache N. Accuracy of anterior intra-articular injection of the glenohumeral joint. Arthroscopy. 2005 Jan;21(1)77-80. doi: 10.1016/j.arthro.2004.09.009 [Crossref][PubMed] [Google Scholar]

48. Weiss J], Ting YM. Arthrography-assisted intraarticular injection of steroids in treatment of adhesive capsulitis. Arch Phys Med Rehabil. 1978 Jun;59(6)285-7. Scholar]

[Crossref][PubMed][Google

49. Andrieu V, Dromer C, Fourcade D, Zabraniecki L, Ginesty E, Marc V, et al. Adhesive capsulitis of the shoulder- therapeutic contribution of subacromial bursography. Rev Rhum Engl Ed. 1998;65(12)7717. [Crossref][PubMed][Google Scholar]

50. Oh JH, Oh $\mathrm{CH}$, Choi JA, Kim SH, Kim JH, Yoon JP. Comparison of glenohumeral and subacromial steroid injection in primary frozen shoulder- a prospective, randomized short-term comparison study. J Shoulder Elbow Surg. 2011 Oct;20(7)103440. doi: 10.1016/j.jse.2011.04.029 [Crossref] [PubMed][Google Scholar]

51. Rizk TE, Pinals RS, Talaiver AS. Corticosteroid injections in adhesive capsulitis- investigation of their value and site. Arch Phys Med Rehabil. 1991 Jan;72(1)20-2. [Crossref][PubMed][Google Scholar]

52. Greaves MW. Anti-inflammatory action of corticosteroids. Postgrad Med J. 1976 Oct;52(612)631-3. doi: 10.1136/pgmj.52.612.631 [Crossref][PubMed][Google Scholar]

53. Valtonen EJ. Double acting betamethasone (Celestone Chronodose) in the treatment of supraspinatus tendinitis- a comparison of subacromial and gluteal single injections with placebo. J Int Med Res. 1978;6(6)463-7. doi: 10.1177/030006057800600608 [Crossref][PubMed] [Google Scholar]

54. Gaujoux-Viala C, Dougados M, Gossec L. Efficacy and safety of steroid injections for shoulder and elbow tendonitis- a meta-analysis of randomised controlled trials. Ann Rheum Dis. 2009 Dec;68(12)1843-9. doi: 10.1136/ard.2008.099572 [Crossref][PubMed][Google Scholar]

55. Wiggins ME, Fadale PD, Ehrlich MG, Walsh WR. Effects of local injection of corticosteroids on the healing of ligaments- A follow-up report. J Bone Joint Surg Am. 1995 Nov;77(11)1682-91. doi: 10.2106/00004623-199511000-00006 [Crossref] [PubMed][Google Scholar] 
56. Halpern AA, Horowitz BG, Nagel DA. Tendon ruptures associated with corticosteroid therapy. West J Med. 1977 Nov;127(5)378-82. [Crossref] [PubMed][Google Scholar]
57. Nichols AW. Complications associated with the use of corticosteroids in the treatment of athletic injuries. Clin J Sport Med. 2005 Sep;15(5)370-5. doi: $\quad$ 10.1097/01.jsm.0000179233.17885.18 [Crossref][PubMed][Google Scholar] 